\title{
Risk Assessment of Groundwater of Sanganer Industrial Area (Jaipur) on Hematology of Swiss Albino Mice
}

\author{
Ravi Kumar Goyal ${ }^{1}$, Kalpana Ojha ${ }^{1}$, Subhasini Sharma ${ }^{1}$, K. P. Sharma ${ }^{2}$ \\ ${ }^{1}$ Dept. of Zoology, University of Rajasthan, Jaipur (Rajasthan), India \\ ${ }^{2}$ Dept. of Botany, University of Rajasthan, Jaipur (Rajasthan), India
}

\begin{abstract}
Blood is primary target to environmental toxicants. Hematological study is an important diagnostic tool and has proved that they may be used as valuable sensitive indicators of toxicity due to different pollutant. Hematological values are widely used to determine systematic relationship and physiological adaptations including the assessment of general health conditions. In the present study, long term exposure (180 days) of groundwater of Sanganer Industrial Area on various Hematological parameters (RBC count, WBC count, $\mathrm{Hb} \%$, $P C V, M C V, M C H, M C H C$, poikilocytosis and anisocytosis of RBC) in Mus musculus.
\end{abstract}

Keywords: Chronic toxicity, Groundwater, Hematology, Swiss Albino Mice

\section{Introduction}

As a consequence of rapid industrialization after the independence, the problem of waste materials in the form of solid or liquid has grown significantly. Untreated effluents and solid waste from industrial units is being discharged or dumped near the factories in open, and is subjected to reaction with percolating rainwater and reaches the groundwater level. The percolating water picks up a large amount of dissolved constituents, reaches the aquifer system, and contaminates the groundwater. Soil porosity supports the percolation rate. Groundwater used for drinking purpose should be free from any toxic elements, living and nonliving organism and excessive amount of minerals that may be hazardous to health.

Textile industry is one of the largest organized sectors in India that provides bread and butter to a majority of the people. These industries generate voluminous quantities of wastewater, either treated or untreated, that causes environmental degradation. Chemical composition of wastewater comprises of several dyes, amines, salts, bleach, acid/alkali and having high concentration of COD, BOD, DO, TH, TDS, EC, Heavy metals like $\mathrm{Pb}, \mathrm{Cu}, \mathrm{Cr}, \mathrm{Fe}, \mathrm{Cd}$ etc.

Sanganer $\left(26^{\circ} 49^{\prime}-26^{\circ} 51^{\prime} \mathrm{N}\right.$ latitudes and $75^{\circ} 46^{\prime}-75^{\circ} 50^{\prime} \mathrm{E}$ longitude) is $16 \mathrm{~km}$ far from Jaipur, Rajasthan (India) famous for its traditional textile printing units. The continuous release of the wastewater from industries and sandy nature of soil of the area, which allows the maximum percolation of pollutants present in the wastewater from industries along the rocks, has affected the physico-chemical characteristics of groundwater.

After the physico-chemical analysis of groundwater of this area, we found heavy metal contamination and changed chemical characteristics (Ojha et al. 2013). Earlier studies showed that exposure of textile waste water at different concentration have affected hematology and biochemistry of fish (Sharma et al. 1999, Sharma et al.2001) as well as rats and mice (Sharma et al.2003, Sharma et al. 2006, Sharma et al. 2007a, Sharma et al. 2009a, Kurde et al. 1993, Kurde and Singh 1995, Mathur et al. 2003a, Mathur et al. 2003b, Suryavathi et al.2005, Sharma et al.2007b, Sharma et al.2009b). However, there is almost no research work on the toxicity of affected groundwater on hematological parameter in mammals. Thus, present study was carried out to investigate the effects of groundwater exposure on the hematological parameters in Swiss albino mice as an experimental animal.

\section{Material And Methods}

The groundwater samples used during the present study were collected from Madrampura, Sanganer, Jaipur (Ojha et al. 2013). The characteristics of groundwater (using APHA, 1989) were as follows: pH 8.0, EC

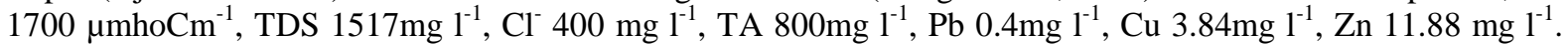
The levels of lead (Pb), TDS, EC, TA was slightly higher than the limits set by the Bureau of Indian Standard, New Delhi (BIS, 1991).

Healthy mature male mice (age: 28-35 days, weighing 30-40gm) were acclimated for one week prior to entry into the experimental protocol. Mice (five per cage) were kept in polypropylene cages $[50 \mathrm{~cm}$ (length) $\times$ $25 \mathrm{~cm}$ (width) $\times 15 \mathrm{~cm}$ (height)] at $25 \pm 3^{\circ} \mathrm{C}$ temperature, $40-60 \%$ relative humidity and 12 -hour alternate light: dark cycle. The mice were fed with measured amounts of standard mice feed (Hindustan Lever Limited, New Delhi, India). Mice were divided into 2 groups-

Group 1 (Control): Standard feed + University tap water

Group 2 (Experimental): Standard feed + Sample Groundwater 
The Animals of both groups were exposed to 180 days. At the end of the experiment, ten animals of each group were anaesthetized by chloroform. Their blood was collected directly from cardiac puncture by sterilized disposable syringe and stored in vials having anticoagulant (EDTA). All hematological parameters viz., hemoglobin concentration (Hb), red blood corpuscle (RBC) count, white blood corpuscle (WBC) count, packed cell volume (PCV) with their indices mean corpuscle volume (MCV), mean corpuscle hemoglobin $(\mathrm{MCH})$, mean corpuscle haemoglobin concentration $(\mathrm{MCHC})$ were estimated by standard methods as prescribed by Dacie and Lewis (1982). The RBC measurements were made by an occulometer standardized with a micrometer scale as parallel magnification (10x X 100x). The percentage of abnormal RBCs was calculated by observing approximately 200 RBCs in 20 microscopic fields (10x X 100x) using an immersion oil.

\section{Statisical Analysis:}

Statistical analysis of the data was carried out using SYSTAT computer program version 5.0. The data are expressed as Mean \pm SEM. Statistical tests (Student's' $t^{\prime}$-test) were applied to find significant difference between values of various parameters recorded for control and treated animals.

\section{Result And Discussion}

Groundwater exposure affected hematology of Swiss albino mice noted in the present study. The results of present investigation indicate profound changes in hematological profile of the test animals treated with groundwater. In comparison to control animals, RBC count (8.9\%), WBC count (7.1\%), Hemoglobin concentration (10\%), PCV (7.4\%) decreased significantly in groundwater samples and $\mathrm{MCH}(1.97 \%)$, MCHC (2.57\%) decreased insignificantly and MCV increased $(0.02 \%)$ insignificantly (Table 1$)$.

\section{RBC Count}

RBC Counts were significantly decreased in the experimental group after long-term groundwater exposure (180 days) to the Swiss Albino mice (Mus Musculus). This may be due to high energy demand of body by toxic stress. Jadhav et al. (2007) have reported decreased RBC count after exposing a mixture of heavy metals including $(\mathrm{Pb}, \mathrm{Cd}, \mathrm{Fe}, \mathrm{Zn}, \mathrm{Cu})$ in Wister Rats. Heavy metal toxicity suppresses the hematopoietic system. In the present study, Lead is found as the heavy metal contaminant in the groundwater. Lead is known for causing oxidative stress in RBCs and resulting anemia. Mohammadhosien et al. (2003), Pathak (2002) and Krishnatray (2002) have reported same results.

Another reason may be decline in Erythropoietin synthesis and secretion. Role of the hormone Erythropoietin is vital in boosting RBC production by Hematopoietic stem cells of Bone marrow. In case of low blood volume or poor blood flow, which leads to tissue oxygenation demand (Hypoxia), it triggers RBC production. $90 \%$ of the hormone is formed in Kidney and $10 \%$ in the Liver. In absence of this hormone, RBC production decline considerably Mathur et al. 2003 and Sharma et al. 2006).

\section{Hemoglobin (Hb\%)}

Hemoglobin carries Oxygen to tissues. Hemoglobin decreased significantly in the experimental group after long-term groundwater exposure (180 days) to the Swiss Albino mice. This is caused due to heavy metal toxicity, as $\mathrm{Pb}$ and $\mathrm{Zn}$ were present in the groundwater. Lead interferes with biosynthesis of Haem by adversely affecting the responsible enzyme system as well as ribosomal degeneration (Iavicoli et al. 2003, Jadhav et al. 2007, Adham et al.2011).

Iavicoli et al. 2003 studied effects of low doses of dietary lead (low dose:0.6-2.0 mg/dL;high dose:2-10 $\mathrm{mg} / \mathrm{dL}$ ) on red blood cell production in male and female mice. Male and female mice receiving below normal background levels of dietary $\mathrm{Pb}$ displayed enhanced red blood cell (RBC) production as measured by increased numbers of RBC and increased hemoglobin. However, as the blood $\mathrm{Pb}$ levels approached $10 \mathrm{mg} / \mathrm{dl}$ there was a marked decrease in $\mathrm{RBC}$ production and $\mathrm{Hb}$ percentage.

Jadhav et al. 2007 studied blood parameters with exposing Wistar rats to a mixture of Heavy metal including Lead, Cadmium, Iron, Zinc and Copper, via drinking water at Indian groundwater contamination levels for 90 days. They reported decrease in RBC count and other parameters. Decrease in $\mathrm{Hb} \%$ was reported by Adham et al. (2011) in their study of effect of mixture of lead, copper, mercury in wild Libyan Jird, Meriones libycus via drinking water in Riyadh, causing decrease in Hemoglobin content as well as PCV.

Heavy metals have high affinity for thiol groups containing enzymes and proteins, which are responsible for normal cellular defense mechanism. Long-term exposure to these metals could lead to apoptosis. Signaling components affected by metals include growth factor receptors, G-proteins, MAP kinases and transcription factors (Flora et al. 2008). Levels of some specific sulfhydrylcontaining enzymes that are inhibited by lead,owing to it's high affinity for them are deltaaminolevulinic acid dehydrogenase (ALAD) and glutathione reductase (GR) (Lachant et al. 1984; Ahmed et al. 2005).. Lead can also bind directly to phosphatidylcholine in 
the RBC membrane, leading to a decrease in phospholipids levels (Lawton et al. 1991; Shafiq and Abdulla 1993).

\section{Packed Cell Volume (PCV)}

Packed cell volume decreased highly significantly. PCV is the measure of blood carrying capacity. It is directly associated with the $\mathrm{Hb} \%$ and $\mathrm{RBC}$ ability to conduct Tissue Oxygenation activity. Therefore, PCV shares the reasons for cause of fall in its level with $\mathrm{Hb} \%$ declined in the present study. Decrease in PCV may be due to lead suppresses bone marrow hematopoietic system, probably through its interference with the enteric iron absorption, Causing Iron deficiency in synthesis of Haem protein of Hemoglobin which (Klauder \& Petering 1977 and Guyton \& Hall 1996). Decrease in PCV is reported by above mentioned research pupil (Mathur et al. 2003, Krishnatrey 2002, Pathak 2002, Iavicoli et al. 2003, Jadhav et al. 2007, Oshode et al. 2008, Adham et al.2011)

\section{$\mathrm{MCH}, \mathrm{MCHC}, \mathrm{MCV}$}

$\mathrm{MCH}$ and $\mathrm{MCHC}$ increased significantly $(0.5 \%)$, while MCV increased insignificantly. These red cell indices depend on RBC count, $\mathrm{Hb} \%$, PCV concentration for the calculation. In the present study, there was insignificant decrease in $\mathrm{MCH}$ and MCHC. While MCV increased insignificantly. They depend on $\mathrm{Hb} \%$ and PCV for the calculation and are inversely proportional. These finding are in support with the fall in $\mathrm{Hb} \%$ and PCV levels, of the present study. Like the present study, study of Mathur et al. 2003 reported insignificant increase in the MCV, MCHC with significant fall in RBC count, $\mathrm{Hb} \%$ and PCV values on exposing Swiss albino mice to Sanganer textile effluent (25 days).Investigation of the toxicity of triethyl lead on some hematological indices has revealed a significant decrease in the $\mathrm{MCH}, \mathrm{MCV}$, and $\mathrm{RBC}$ count by Yagminas et al.(1990); and on similar exposure to Lead acetate by Mohammadhosien et al. (2003). Above-mentioned authors-Pathak 2002 and Krishnatrey 2002 found fall in MCV, MCHC as observed in the present study.

\section{WBC Count}

There is a significant decrease (5\%) in WBC count. Suppression of the haemopoetic system, in turn reduces the production of WBCs. The reason is supported by the study of Mathur et al. (2003), who exposed adult swiss albino mice to Sanganer textile effluents for acute toxicity study(25 days).They reported decline in WBC count, owing to bone marrow depression. Similarly,Iavicoli et al. (2003) studied Effects of low doses of dietary lead on white blood cell production in male and female mice. It showed fall in Leucocytosis, Lymphocytosis is reported by Adham et al. (2011) in their study of effect of lead, copper, mercury in wild Libyan Jird, Meriones libycus in Riyadh. However contrary to the present study, Pathak 2002 reported increase in WBC count after exposure of Sanganer groundwater for 180 days. This indicates the effort to face the toxic stress.

\section{Variation in Blood cells Size $(\mathbf{R B C s})$}

There is significant decrease in size of red blood cells and highly significant increase in size of white blood cells in the present study (Table 2). The decrease in red blood cell size may be attributed to osmoregulation disturbance, causing loss of erythrocyte membrane integrity, leading to cell shrinkage (microcytosis). One of the reasons may be fall in $\mathrm{Hb} \%$. Erythrocyte division in the bone marrow is governed by the hemoglobin concentration. Cell division stops when a critical hemoglobin concentration has been reached. Therefore, if hemoglobin production is defective (as occurs in iron deficiency), erythrocytes continue to divide until that hemoglobin concentration is reached. With each division they become successively smaller. It is further supported by insignificant increase in MCV in present study. Another reason for this microcytosis in shunting is thought to be due to altered iron metabolism from liver dysfunction and usually resolves with successful shunt closure. This is supported by Liver histopathology observations in present study. However, the other most commonly occurring observation is opposite to the present study results. There is significant increase in the cell size owing to the facts-cellular swelling or Lack of either or both vitamins, the Vitamin B-12 or Folic acid, causes diminished DNA and Nuclear Maturation(as they are vital for DNA synthesis and RBC maturation), following slow rate of nuclear and cellular division of the RBC cells (Guyton and Hall 1996). It results in production of extra larger than normal average daughter cell in size. They are called macrocytes-large oval, in place of biconcave disc. These poorly formed cells after entering the circulation system, are capable of carrying Oxygen to tissues, however, due to the fragility, they are short-lived cells. Pathak 2002 reported increase in mice RBC cell size on exposure to Sanganer groundwater.

In the experimental group, abnormal RBC cell types like acanthocytes, burr cells and spherocytes have reported. Ojha et al. 2013b also reported poikilocytosis in RBCS after groundwater exposure in Poecilia reticulate ret. Among abnormal types, acanthocytes, burr cells and spherocytes were the prevalent forms associated with low toxicity as noted in mice (Sharma et al.2007b). 


\section{Conclusion}

From the present study, it is clear that due to presence of heavy metals and changed physico-chemical nature of the groundwater have affected the hematological parameters of the Swiss albino mice. Study was done to see the possible risk assessment on the human health if any possible action has not taken to short out this problem. Finally, this is suggested that groundwater mitigation and effective technology is required to control this problem, as the groundwater is the basic need of human beings.

\section{Acknowledgments}

Authors wish to express their sincere thanks to the Head, Department of Zoology and Head, Department of Botany, University of Rajasthan, Jaipur to provide technical support; Department of Biotechnology, New Delhi and Department of Science and Technology, Jaipur for financial support.

\section{References}

[1]. Adham K.G., Al-Eisa N.A., Farhood M.H. Impact of heavy metal pollution on the hemogram and serum biochemistry of the libyan jird, Meriones libycus. Chemosphere. 84(10):1408-1415. 2011

[2]. APHA. Standard methods for examination of water and wastewater. $17^{\text {th }}$ Ed. Washington DC. 1989.

[3]. Dacie, J.V., Lewis, S.M. Practical hematology. $6^{\text {th }}$ Ed. Churchill Livingstone, London, UK. 1982..

[4]. Guyton C. and Hall J.E. Textbook of Medical Physiology. Ninth edition,Prism Books Pvt Ltd. Bangalore.India. ISBN 81-7286-034X. 1996.

[5]. Iavicoli I., Carelli, G., Stanek, E. J., Castellino, N., \& Calabrese, E. J. Effects of lead acetate administration on mouse hepatocyte survival. Toxicology letters. 129(1): 143-149. 2002.

[6]. Jadhav S. H., Sarkar S. N., Ram G. C., Tripathi H. C. Immunosuppressive effect of subchronic exposure to a mixture of eight heavy metals, found as groundwater contaminants in different areas of India, through drinking water in male rats. Archives of environmental contamination and toxicology. 53(3): 450-458. 2007.

[7]. Klauder D.S., Petering, H.G. Anemia of lead intoxication: A role of copper. Journal of Nutrition. 107: 1779-85. 1977.

[8]. Krishnatrey R. Dysfunction of Vital and Reproductive Organs in Swiss Albino Rats Following Exposure to Textile Wastewater Effluents. Ph.D. Thesis. University of Rajasthan. Jaipur. 2002.

[9]. Kurde S. Congo red induced changes in hemato-biochemistry of the albino rats. Himalayan Journal of Environment and Zoology 7, 13-16. 2002

[10]. Kurde, S and Singh R. Effects of two samples of textile effluents and dyes on total erythrocyte counts and related parameters of Wister rats. Proceedings of Academy of Environmental Biology 4, 177-181. 1995.

[11]. Mathur N, Krishnatrey R, Sharma S, Pathak Shipra Sharma K P. Certain hematological responses in Swiss albino mice following exposure to textile dye wastewater.J.Environ.Biol.-Journal of Environmental Biology.24(2):161-164. 2003.

[12]. Mohammadhosein N. M., Heidari Z., Sagheb H.M., Barbarestani M. Effects Of Chronic Lead Acetate Intoxication On Blood Indices Of Male Adult Rat. Daru .11(4):147-151. 2003.

[13]. Ojha, K.. Goyal, R.K., Sharma, S., Sharma, S., Yadav, A., Yadav, N. and K.P. Sharma. Impact of colourful textile prints on groundwater quality of Sanganer Jaipur, Rajasthan (India). Pollution Research. 32(3): 595-98. $2013 \mathrm{a}$.

[14]. Ojha, K.. Goyal, R.K., Sharma, S., Sharma, S., Yadav, A., Yadav, N. and K.P. Sharma. Effects of Groundwater on the hematology of Poecilia reticulate after long term exposure in Microcosm. Indian Journal of Environmental Science. 17(1): 75-80. 2013b.

[15]. Oshode O.A., Bakare A.A., Adeogun A.O., Efuntoye M.o., Sowunmi A.A. Ecotoxicoloical assessment using Clarias Gariepinus and microbial characterization of leachate from Municipal Solid waste landfill. International Journal of Environment Research. 2(4):391-400. 2008.

[16]. Pathak S. Blood Biochemistry and Histopathology of Selected Organs of Albino Rats [Rattus Norvegicus (Berkenhout)] Exposed to Textile Dye Wastewater of Sanganer. Ph.D. Thesis. University of Rajasthan. Jaipur. 2002.

[17]. Sharma KP, Sharma S, Subhasini, Kumar S, Singh PK, Grover R and Sharma PK. A comparative study on characterization of textile wastewaters (untreated and treated) toxicity by chemical and biological tests. Chemosphere 69: 48-54. 2007a.

[18]. Sharma Subhasini, Kalpana, Arti, Shweta, V. Suryavathi, Pawan K. Singh, Ramesh, Shipra and K.P. Sharma. Toxicity Assessment of Textile Dye Wastewater Using Swiss Albino Rats. Australasian Journal of Ecotoxicology. 13: 81-85. 2007b.

[19]. Sharma, S., Kalpana Sharma, Nidiveta Yadav, K.P Sharma..Alterations in Biochemical and Histopathological Profile of Liver in Distillery Soil Leachate Treated Swiss Albino Mice(Mus Musculus).Pharmacologyonline (3):1047-1053. 2009b

[20]. Sharma, S., Sharma, S., Sharma, K.P. A comparative study on the toxic effects of textile dye wastewaters (Untreated \& Treated) on mortality and RBC of a freshwater fish Gambusia affinis (Baird \& Gerard). Journal of Environmental Biology. 27(4): 623-628. 2006.

[21] .Sharma, S., Sharma, S., Singh, P.K., Swami ,R.C., Sharma, K.P. Exploring Fish Bioassay of Textile Dye Wastewaters and their selected constituents in terms of mortality and Erythrocyte disorders. Bulletin of Environment Contamination and Toxicology. 83: 29-34. 2009a.

[22]. Suryavathi V. Clinical investigation on the reproductive systems of Swiss albino rats and mice exposed to textile dye wastewaters (untreated and treated) of Sanganer, Jaipur. Ph.D thesis, University of Rajasthan, Jaipur, India. 166 pp. 2005.

[23]. Yagminas, A.P., Franklin, C.A., Villeneuve, D.C., Gilman, A.P., Little, P.B., Valli, V.E. Subchronic oral toxicity of triethyl lead in the male weanling rat. Clinical, biochemical, hematological, and histopathological effects. Fundamental of Applied Toxicology. 15: 580-596. 1990

Table 1: Effects of groundwater on hematological parameters in Swiss albino mice after chronic treatment

\begin{tabular}{|l|l|l|}
\hline Parameters & Control & Experiment \\
\hline RBC $(\mathrm{x} 106 / \mathrm{mm} 3)$ & $7.61 \pm 0.24$ & $6.99 \pm 0.10(-8.9 \%)^{* *}$ \\
\hline WBC $(\mathrm{mm}-3)$ & $4009 \pm 82.9$ & $3743 \pm 53.8(-7.1 \%)^{*}$ \\
\hline $\mathrm{Hb}(\mathrm{g} \%)$ & $12.4 \pm 0.21$ & $11.3 \pm 0.19(-10 \%)^{* * *}$ \\
\hline PCV $(\%)$ & $44.9 \pm 0.57$ & $41.8 \pm 0.52(-7.41 \%)^{* * *}$ \\
\hline
\end{tabular}


Risk Assessment of Groundwater of Sanganer Industrial Area (Jaipur) on Hematology of Swiss Albino

\begin{tabular}{|l|l|l|}
\hline $\mathrm{MCV}(\mathrm{fl})$ & $59.9 \pm 1.78$ & $60.01 \pm(+0.02 \%)$ \\
\hline $\mathrm{MCH}(\mathrm{pg})$ & $27.7 \pm 0.62$ & $26.9 \pm 0.71(-2.57 \%)$ \\
\hline $\mathrm{MCHC}(\%)$ & $16.5 \pm 0.65$ & $16.2 \pm 0.35(-1.97 \%)$ \\
\hline
\end{tabular}

Data in parenthesis represent \% decrease/increase in the values in comparison to control. Significant at 5\%*, $1 \% * *$, and $0.1 \%$ ***. RBC- Red Blood Cells, WBC- White Blood Cells, Hb- Hemoglobin, PCV- Packed Cell Volume, MCV- Mean Corpuscular Volume, MCH- Mean Corpuscular Hemoglobin, MCHC- Mean Corpuscular Hemoglobin Concentration

Table 2: Size of RBC and Lymphocyte $(\mu \mathrm{m})$ in control and experimental mice

\begin{tabular}{|l|l|l|}
\hline Parameters & Control & Experiment \\
\hline RBC & $6.41 \pm 0.12$ & $5.94 \pm 0.11(-9.36 \%)$ \\
\hline WBC & $8.34 \pm 0.13$ & $9.17 \pm 0.11(+9.05 \%)$ \\
\hline
\end{tabular}

Data in parenthesis represent $\%$ decrease/increase in the values in comparison to control. Significant at 5\%*, $1 \% * *$, and $0.1 \% * * *$. RBC- Red Blood Cells, WBC- White Blood Cells 